\title{
The Case For and Against Indexation: An Attempt at Perspective
}

\author{
JAL-HOON YANG
}

I

N THE 1930s, when widespread unemployment was the economic malaise threatening the foundation of a free society, Professor John M. Keynes, of King's College, prescribed fiscal activism as a cure. Now in the 1970 s, rampant inflation is seen by some to threaten the viability of a free society. Professor Milton Friedman, of the University of Chicago, has prescribed indexation as an effective expedient to preserve a free society. ${ }^{1}$

Indexation proposals, however, have encountered historically less-than-enthusiastic receptions in many quarters, in spite of the advocacy by many eminent economists. This article seeks to wneil some of the less apparent aspects of indexation in order that one may acheve a deeper understanding of the theoretical and practical issues involved.

\section{GENERAL BACKGROUND OF INDEXATION}

Indexation, or index-linking, refers to proposals to link the number of dollars to be delivered on a contract to changes in some specified price index. Under indexation, money would continue to be used as a medium of exchange and as a measure of value, but not necessarily as a standard for deferred payments. In the event that the purchasing power of the dollar changed as indicated by an agreed-upon price index, contracts would be honored in terms of a unit of con-

\footnotetext{
1Miton Friedman, "Using Escalators to Help Might Infation" Fottune (July 1974), pp. 94-97, 174-76.
}

stant purchasing power over "goods and services in general." "Thus, an index-linked contract to deliver $\$ 100$ a year from today would deliver $\$ 110$ if prices rose by 10 percent over the interval, that is, if the purchasing power of the dollar declined by 9.09 percent.

\section{Coverage}

The basic objective of indexation is the insulation of contractually-created claims on output from the effects of changes in the purchasing power of money over goods and services in general (inflation or deflation). In a completely indexed world, all of the following would be indexed: all private and public wage and loan contracts including deposits at thrift institutions, insurance, and pension contracts; social securicy and other transfer payments, including unemployment compensation; and, of course, govermment tax receipts. With respect to taxes, indexation would apply mainly to income taxes by adjusting the level of exemption, the tax brackets, and the base of asset valuations. The progressive income tax rate itself would remain invariant for a given social decision regarding the relative size of the govermment sector. Since profit shares are noncontractual items and are

\footnotetext{
With changes in relative prices, the constant purchasing power of money over "goods and services in general" necessarily implies varable purchasing power over at least some of the goods and sorvices in the basket; that is, with relative price changes, the "index nimber problen" ineviably creeps in. See Ragnar Frisch, "Anmual Survey of Economic Theory; The problem of Index Numbers," Econometica (1936), pp. $1-38$.
} 
detemined residually, they would not be molned." However, to the extent tatat such contracts as those for purchases of materials are indexed, it appears likely that profit shares of some intemediate goods producers wondd be indiredly protected thougl indexation.

Even money wotid be indered under a completely indered economy. "In a pure currency economy without private noney producers (banks), indexation of cumencies could be faclitated by dating thom, such as Sylvo Gessell's stamp money proposal. With bankcreated money and legal reserve requirements, the task would be more diffent and would require frequent intervention by the central bank.

\section{Experiences With Indexation}

A review of roreign experience with regard to indexation shows a wide variety of practices with respect to the classes of contracts indexed, the extent of the compensation allowed, and the choices of indices to which the contacts are tied. "The most comprehensive indexation was provided initally by Finland and then by Israel, France, and most recenty by Brazl. In adution to emplovment contracts, various loan, insurnce, and pension contracts have been tied to a number of price indices as well as to the price of specifc foreign exchange and commodities, such as that of gold $\mathrm{Napoleons}$ in the case of France. The Peoplex Republic of China first introdtoed the indexation of bank deposts in 1949 , followed by Finland in 1955 , and more recently by Brazil in 1965.

Experience wh indexing lom contracts in the United States and the United Ingdom has been scanty, Irving Fisher prevaled on the pand Kardex Company in 1925 to issue bonds tied to the wholesale price index, but these bonds were soon converted into preferred stocks and ordinary bonds. ${ }^{7}$ The United

\footnotetext{
Miton Friedman, Price Theory (Chicago: Aldine Publishirg Company, 1962), p. 99

SWliam f. Bammol "The Escalated Economy and the Stmulating Erects of Intaton," in Essays in Honour of harco Fonmo, wol. 2, ef. Tullo Bagioth (Padova, taly: Edizani Cedam, 1966 ), po. 96.104.

Tror a full discussion of Gesell proposal se fohn M. Keynes, General Theory hew Yok: Harcoun, Brace and Company, $1935), \mathrm{pP} .357-58$.

GDavid Finch, "Prurchasing Power Guemantees for Deferrad Payments," Mntematonal Mometory "und Sraf Papers ( Case for Indexing" and Nige Athans, "rye Gase for the U.K. Indewng Gits, Euromoney (Jume 1974), pp. 19-27, and United Nations, Economic Commission for Latin Amer ica, "Index Clauses in Deferred Payments" Economic Buletin for Latan America (October 1957), Pp. $73-89$.

Tenomic Commission for Latin America "Inder Clauses in Deferred Payments, p. 76 .
}

Kingdom did not adopt indexation for loan contracts until 1973. The number of people whose incomes are partially protected by moxation in the United States has increased Cramaticaly in the past several years, mainly through the wider use of escalator clauses in labor contracts, the adoption of indexed social security payments, and the hood stamp program.

\section{Fallure to Gain General Suppor}

Indexation has historically enjoyed the support of many illustrious economists, such as Stanley Jevons, Afred Marshall, Irving Fisher and John M. Keynes. Until the end of World War $M$, however, indexation had falled to elicit the support of policymakers or capture the interest ot the general public. ${ }^{8}$ The fundamental reason appears to be that the economists who adrocated such proposals had not designed an acceptable means for their implementation. They tended to emphasize the desirability of the proposal as if ". . we had a clean sheet of paper to write upon." Too often they faited to consider explicity how the new arrangement would afect exsting institutions and outstanding comminments. Otteu missing was a comprehensive analysis of the likely distribution of the total costs of transition. An important subsidiary exphation for the failure of indexation to elicit popular support appears to be the implict public judgment that the economics profession has not, as yet, provided a generally acceptable index of price change. ${ }^{10}$

\section{THE CASE PRESENTED FOR INDEXATON}

The fundamental case for indexation, in essence, rests on the claim that it would approximate the results associated with a stable price level - even in the absence of price level stability, ${ }^{11}$ The theoretical

\footnotetext{
dFor a historical overview, see Finch, "Pumbaring Power Guarantees," pp. $1-22$

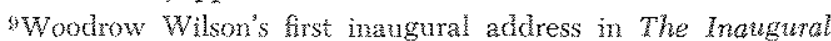
Addresses of the Anerican Presidents, nnotated by bavis Newton Lot (New Tork: Yols, pinehar and Winston, 1963 ). 0. 201 . This partin anote refers to the founding of the Federat Rosme System and is disolayed mside the en trance to the Federal Resere Bulding in Washington D.G. "We shall chel with our ecomomic system as it is and as it nay be rnodited not as it might be if we had a clean sheet of paper to write upon; and step by step we shall make it what in should be"

10Beramin Kein, "The Measurement and Social Costs of Inhtion "The Recent Infation and Our Wew Monetary Standard, mponlished paper (Los Angeles: Uriversty of Califomith, Los Angeles, 1974 ).

11rving Fiser. The Purhasing Power of Money, $2 \mathrm{nd}$ ed rev. (New Fork: Angustus M. Kelloy, Bookseler, 1963), and Stabilizing the Dolar, (New York: Macmilan, 1920); Alrred Warchall, "Temedtes for Fluctuations of General Prices," Memonals of Afred Marshall, ed. Ambur C. Pigou (New

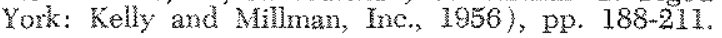


presumption in favor of price level stablity is that a fluctuating price level has undesirable effects on the distribution of income and on the efficient utilization of resources. In addition, the argument has recently been advanced that indexation would help to acheve price level stability.

\section{Distributive and Allocative Elects of an Unstable Price Level}

Inflations have real consequences when they are imperfectly anticipated. Even when perfectly anticipated, inflations affect allocative decisions.

Income Dismibution - From the point of view of equity in the distribution of wealth, a stable price level is superior since the redistributional effects of a less than fully anticipated inflation do not occur. The distributional implications of imperfectly anticipated inflation depend crucially on the existence of binding contracts fixed in nominal monetary units (monetary contracts, hereafter). For a given stock of existing monetary contracts, be they loan or employment, the magnitude of distributional effects depends positively on the gap between the actual and the anticipated rate of inflation at the time of contract formation. If all the ransactor units were neither net monetary debtors nor creditors, there would be no distributional effects. ${ }^{12}$ In the event of an under-anticipated inflan tion, net monetary debtors gain and net monetary creditors lose; the conclusion is reversed in the event of an over-anticipated inflation. The opposite distributional effects occur during a deflation.

The effects of imperfectly anticipated inflation on the distribution of income generally have been considered undesirable. As Irving Fisher, who pioneered the seminal distinction between anticipated and unanticipated infation, put it, “... the real evils of changing price levels do not lie in these changes per se, but in the fact they uswally take us unaware. It has been shown that to be forewamed is to be forearmed, and that a foreknown change in price levels might be so taken into acoount in the rate of interest as to neutralize its evils." 13

Resoumce Allocation - In a money economy the commodity called money performs the services of col. lecting information and facilitating exchange between all participans in transactions. In an anticipated stable price environment, money is believed to promote

\footnotetext{
12weuber A. Kessel and Amen A. Alchian "Fffects of Inflation," Jostral of Political Economy (December 1982), pp. $521-37$

13) Fisher, Purchasing Fower, p. $32 \mathrm{l}$.
}

efficiency by freeing other resources from the task of information gathering. ${ }^{1 *}$

When the price level changes rapilly and is anticipated to any extent, the holding of money becomes more costly and its seryices less efficient. Other resources are then drawn into the perfornance of money services, leaving less resources available for the production of goods and services. This inflation-induced reallocation of resources would shink the effective, as distinct from the notional, production possibility hontier, thereby reducing the amount of goods and services available for present and future consumption. ${ }^{\text {ta }}$

\section{Indexation Helps Achieve price Level Siabilty}

Traditionally, the advocacy of indexation was based on distributive equity and, to a lesser degree, on allocative efficiency grounds. ${ }^{16}$ Recently, a third dimension, based on a dingnosis of the underlying cause of modern inflation, has been added. The modern day proponents of indexation, represented by Professor Friedman, have thrown in a sweetener. They claim that indexation would tend to restore price level stability in an existing inflationary situation. Their position can be interpreted to be based on their implict diagnosis that inflation is a "political phenomenon."17

Their argument would run as follows. Inflation occurs as a result of an increase in a nation's money stock in excess of the ability of the economy to produce goods and services. Usually the initial force leading to inflation is increased demand for govermment expenditures to aid various sectors of the economy or segments of the population. Those demnding grenter government services may not even be aware of the inflationary consequences of their actions. It is only necessary that in striving to better their relative and absolute

\footnotetext{
14Given imperfect Foresight, a variable monetary yardstick (impled by a fluctuating price level) increases the uncertainty associated with any monetary contract and, assmming aversion to purchasing power risk, increases the cost of reaching agrement.

15 Robert Clower, "The Keynesian Comterevolution: A Theoretical Appraisal," in the Theory of Interest Rates, ed. Frank I. Hahn and Frank P. R. Breching (London: Macmillan and Co. Lte, 1965), pp. 103-25. Clower's distnction between notional and efective denand has been adapted here.

107nch, "Purchasing Power Guarantess," pp. 1-22, and $W$ Stanley fevons, Monet and the Mechanism of Exchange (New York: Twentieth Century Press), p. 91.

17Toan Lobinson, "Quantity Theories old and New," Joumal of Money, Credit and Banking (November 1970), p. 512 . The term "political phenomenor" was coined by Robinson in the article. The ixutaposition of the term, with the resulting implications for indexation, is that of the author's.
} 
positions they induce an acommodating increase in the nominal money stock which is faster than would be consistent with price level stability.

In this interpretation of their view, athough the villain fostering the infation is the public demandma more from goverment, the basic cause is much deeper. It is imbedced in our system of "advocacy politics." "Those who are ultimately responsible for infation are those who succeed in inducing the govgrment to try to command a greater share of soviety's resources than is explicity provided for in tax laws.

\section{THE CASE PRESTNTED AGAINST INDEXATTON}

Historically, indexation has been proposed at times of on going and relatively high rates of price change. The case generaly advanced aganst such a proposal has been based primanly on the fact that we do not start with a "clean sheet of paper to write upon." Since at any moment there exist outstanding contracts which are not indexed, it is argued that indexation would tend to cause problems for those individuals and institutions involved in such contrats.

An additional standard argument against the indexing proposal has been that the acloption of such a proposal would tend to weaken support for antindation policies. More recenty, some have contended that indexation would tend to aftect adversely the terms of international trade for an open ecomomy.

The following statements were made by the Councl of Economic Advisers and others in 1952 in opposition to the proposed issiance of a purchasing power bond by the Treasury. These statements are representm ative of the argumens used against indexation in general

\section{Would weaken support for andithlation actions}

The issuance of a purchasing power bond would imply a defeatist attinte toward the problem of infation. Widespread ownership of purchising power bonds would add another group to those who think themselves sheltered from the ffects of inflation, and would weaken public support of a stabilization program.

The proposal for purchasing power bonds applies the principle only to a limited amount of bonds. The Goverment would thus add an admittedly at-

18 Ceprge P. Shutz, "Teflections on Poltical Economy," Jotrnal of Finance (May 1974), pp. 323430.

10. S. Congres, Joint Committee on the Economic Report, Monctary Polcy and the Manggement of the Public bebt, Part 2, 82nd. Cong., 2nd. sess, 1952, pp. 888-89, 1097, 1109. tractive feature to one type of securty onered to the public in competition with oher Govemment bonds and such other foms of assets or contracts as anrency, demand, time and savings accomts, shares in savings and loan associations, and life insurance phicies. It is very ikely that great pressure would develop to extend the purchasing power clause also to other investments, public and private. "the greater the rumber of persons who considered hemselves shidded from infliton, the greater woud be the possibilty of ins occurence.

\section{Woud ham some individrals and institurons}

The demeris of the proposal are cleat and compelling. First the issuance of a Covemment bond, the value of which was guaranted in tems of purchasing power, wonld place ocher forms of hxedinterest investnent at a decided disadvantage and would jeopardize the continued existence of such other forms of investment. There would be raised, therefore, the serious problem of ramess to sawers who already had their savings programs in effect. Moreover, it appears inevitable that he adoption of a constant purchasing power Gotrement bond would lead to a disastrous collapse in the value of outstanding investment media.

\section{Would be dificut to choose appropriate inder}

The determination of the index measuring the price at which the bonds would be repaid would present technich diffoulties and - no natter how decided would result in popular alissatifaction.

\section{Would weaken tems of intemationat tade}

A new dimension in kems of an open economy contex has been injected recenty. Based on the premise that indexation would nocelerate inllation, Professor Muray L. Weidenban objects to indextion on the ground that:

We do not live in a closed economy. We already have seen that accelerating infation thome mens devaluation of our curency abrod. That brings dem terionation in the tems of trade and dechines in our real standard of living:o

\section{ASSRSSMENT OR WIT ARGUMENTS}

Both sicles of the debate appear to agree hat (1) an infationless altematye is ideal, and that (2) indexarion would prevent the emergence of inflation induced distributional efects (making "living with infation" easier).

As mentioned earlier, the proponents tend to ignore the transitional costs nvolved in adoping indexation,

\footnotetext{
"Momray L Weidenbanm, "The Case Against "Indexing", Duth's (July 1074), p.11.
} 
while the opponents tend to emphasize the likely effects on the viability of certain existing institutions. With regard to the inflationary implications of adopting indexation, the proponents and the opponents are diametrically opposed.

To help assess the pros and cons of indexation, let us first speculate on the properties of an idealized, completely indexed economy. Such speculation would help to illuminate the possible difficulties accompanying any period of transition to necessarily lessuthancomplete indexation. 21

\section{Some Properties of a Completely Indexed Economy}

Relative Price Changes - It might appear that in a completely indexed economy, the relative prices of various goods and services would remain constant. Indexation, however, does not immunize a producer from the risk of changes in relative prices incident to changes in preferences, technology, or weather. A set of relative (output) prices would still guide the allocation of resources. Indexation is designed to insure only the equality between the realized and the contracted clains on output for the hired factors of production.

Government's Claims On Resources - The share of resources commanded by and flowing through the government would ideally not deviate much from the level that the public "voluntarly" transfers through its pledges of current and future tax payments. The govermment would be deprived of the power to collect inflationary taxes from the populace. The income tax system, with indexed exemptions, asset revaluations, and indexed tax brackets, wonld lose a considerable amount of "Bult in" stabilization potency widely thought to be associated with a progressive tax structure. ${ }^{22}$ However, should the govermment attempt, through continued creation of money, to command more real resources than those tendered in explicit tax payments and private-sector lending, inflation would persist and the price level conld approach infinity.

Existence of Inflation - An intriguing question arising in this context is the consequence of moving into

\footnotetext{
21 A real-world exchange economy cannot have its noney indexed and still remain viable. See Bamol, "The Escalated Econony," pp. 96-104, and Amotz Morag, On Taxes and Inflation (New York: Random House, Ine, 1065), pP. $144-73$.

y2arthe Deceptive Lare of Indexation," Business Week, 25 May 1074, pp. 147-52.
}

a regime of indexation from the initial position of infationary disequilibrium. Without indexation, a given rate of inflation may eventually be eliminated by the inflation-induced changes in income and wealth distribution. A completely indexed economy would be devoid of this mechanism, and henoe would bring into the open the underlying confict of interest existing among the competing clamants.

Absence of Money Illusion-Various foms of "money illusion" would be completely absent from the system. Money illusion would be absent in wage negotiations. The absence of money illusion in wage perceptions would tend to "worsen" the terms of the short-run trade-of between inflation and unemployment in the sense that no amount of inflation would buy less memployment; that is, the short- and longrun Plillips curves coincide, being vertical at the natura inemployment rate ${ }^{23}$ This factor would tend to reduce opposition to an antinflation policy. In addition, the behwior of interest rates on loans as well as negotiated wages wonll tend to stablize since they would not embody anticipations of inflation.

Infomational Efficiency of Markets - More extensive use of the markets would be encouraged under indexation for intertemporal exchange and transformation of resources. To the extent that the costs of collecting and processing the information regarding productive opportunities are lowered through market exclange, real output would be increased for a given structure of preferences and a given state of technology.

Risk-free Asset-Indexation provides assets which are free of purchasing power risks. A short-tem monetary asset in this regime, such as Treasury bills, wonld be free of purchasing power risk in addition to defanlt and relative price risk associated with changes in interest rates. The availability of such an asset would rescue much of the theoretical results of the modern capital pricing and portolio choice theories which are predicated on the existence of a riskless asset. ${ }^{2 \frac{4}{4}}$

\section{Potential Impact of Indexation on Inflation}

Although indexation, by itself, would not prevent price level changes, the advocates appear to believe

\footnotetext{
waror a discussion of short- and long-run Phillos curves, see Roger Spencer, "The Relation Between Prices and Employment: Two Views," this Review (March 1969 ), pp. 15-21.

24 Marshall Samat, "Furchasing Power Risk, Porfolo Analysis, and the Case for molex-Linked Bonds," Joumal of Money, Credit and Bonking (August 1973), pp. 836-45.
} 
indexation would reduce inflation by reducing the pressure for inflationary policies and by making antiinfationary policies more palatable. The opponents of the proposal argue that indexation is likely to exacerbate inflation since by removing its sting, the constituency for anti-infationary policies would be weakened. They recommend more resolute anti-inflation policies, but seldom provide an analysis of the underlying force driving infation.

What is critically missing in the argument that indexation would lead to accelerating inflation is the analysis of why inflation occurs. In the absence of any analysis as to the incentives and the mechanics of inflation, a case based on the fears of accelerating inflation (which is conceded to be "functionless" in terms of distributive benefits) is not very persuasive.

As noted earlier, the proponents provide such an analysis of infation in terms of advocacy politics and the share of resources commanded by the government. From this perspective of the diagnosis of inflation, it is the government-deficit-induced increase in the nominal money stock which underwrites persistent inflation. The issue fundamental to the inflationary implication of indexation, then, may be posed as: is indexation more likely to lead to the abatement of pressures for policies which lead to inflation?

The advocates of indexation answer the query affirmatively. They cite the reduced incentives to promote inflationary policies under indexation as well as the asserted reduction in the costs of anti-indation policies to bolster their case. Their case would be more perstrasive if one could accept their implicit premise that taking the "honey" out of inflation would reduce the pressures for policies which are likely to lead to deficits, excessive monetary growth, and the entailed inflation. As was touched upon earlier in discussing the inflationary implication of moving into complete in. dexation from the initial condition of infationary disequilibrium, their implicit premise is not based on a firm foundation.

\section{Why Atrempt to Reduce Inflation Under Complete Indexation?}

The modern proponents of indexation seldom make explicit what additional benefits they perceive for the asserted abatement of inflation if its distributional effects are neutralized under indexation. Passing references to the nuisance of bookkeeping changes are made. However, the possible gain in allocative effciency associated with the infationless solution alluded to earlier is seldom made. If, as the proponents argue, indexation neutralizes the distributive effects of inflation, isn't the presumed anti-inflation beneft of indexing simply superfious without some amplification of the effects on resource allocation and balance-ofpayments developments?

In evaluating the balwnce-of-payments effects, one must take into consideration the prevailing foreign exchange rate system and whether or not indexation will lead to more or less inflation. Under a freelyfuctuating exchange rate system, the case for indexation would not be affected by its balance-of-payments effects, regardless of its effects on inflation; exchange rates would simply change to refect changing rates of inflation. Under a fixed exchange rate system, however, the case for indexation would be greatly attenuated if it results in accelerated inflation, as some opponents contend. This is so since the likely consequences would include increased restrictions on product and capital flows to cope with the emerging balance-of-payments difficulties.

\section{A. Recent Experience With Indexation and Inflation}

Some of the proponents of indexation have cited the example of Brazil as a case in which adoption of indexation has both reduced inflation and increased growth of output. Interpretations differ as to the role that indexation played in the Brazilian "mir. acle." Friedman suggests that indexation contributed both to accelerated growth and decelerated inflation. Both Watter W. Heller and Ronald A. Krieger tend to emphasize the incidental contribution of indexation to growth. They assert that the main spring of growth was the enforced redistribution of income to capital from labor which could have occurred only in a regimented command economy. They leave unexplained the deceleration of inflation.

Our reading of the Brazilian experience suggests that both occurrences are the predictable effects of conscious policy choices made by the government with the tacit approval of the populace. The government of Brazil replaced inflationary taxation as the dominant form of a savings-investment technology in 1964 with financing through capital markets and direct taxation, The motive for this action was the realization that the yield of inflationary finance had atrophied alarmingly as people increasingly made adjustments by such devices as capital fight abroad and

\footnotetext{
"David M. Trubek, "Law, Planning and the Development of the Brazilian Capital Market," The Bulletin (New York: New York University, April 1971), pp. 20-21.
} 
barter transactions. The consequent massive reforms in tax laws, tax aministation, and in the capital market regulations proved efrective.

Ingenious tax lincentives, such as granting tax credits for the purchase of shares in the so-called 157 Funds (specially created mutual invesment inds), which are then used to purchase new and secondary equity issues, stimulated the development of equity markets and promoted savings. ${ }^{2 \%}$ The government, in effect, used the tax system to elicit savings, but relied on the newly developed capital market and the price system to allocate the savings thus created.

But the single force which contributed most to the decelerated inhation was the govermment's conscious and deliberate policy of reducing deficits. The abandonment of inflation as a savings-investment technology must be credited for checking inflation, not the indexation per se. The adoption of indexation, coincident with the move toward less inflationary policies, served primarily to eliminate the infation induced income distribution. Its contribution to the deceleration of inflation was accommodative rather than causal.

Economic growtil in Brazil can be explained at least partially in terms of the increase in forced savings induced by changed tax laws. In addition, the increase in allocative efficiency arising from the matket direction of resource fows may be construed as a contributing factor to the observed growth in Brazil.

It must be noted that in Brazil there are relatively small amounts of outstanding monetary contracts. Since the existence of monetary contracts complicates the implementation of indexation, it is likely that opposition to such a proposal would be more muted in a country like Brazil than in the United States.

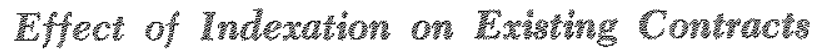

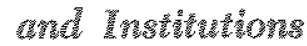

Profossor Friedman strongly favored the issuance of the purchasing power bond in 1951 and based the continuation of his advocacy mainly on equity and ethical grounds. He subsequently broadened the scope

\footnotetext{
46lbid. pp. 22, 25. The Capital Market Law of 1965 anthorized monetary correction for debt instruments and bank deposits, and introtuced authorized but inissued shares. The Law also removed effective bariers to indexation and lending at positive real mates in an infationary environment with lisury limits of 12 percert, except in the shotwterm letra market (a letra is comparable to a banker's acceptarce).

27 1 bid., pp. 56m65.
}

of his proposal by induding private securties and the income tax systems (1973). Reinforced by the "economic miracle" wrought by Brazil with an issist from "monetary conrection" and compelled by accelerating inflation domestically, he has reconty mounted a vigorous campaign for indexation reminiscent of his advocacy of freely-fuctuating exchange rates and monetarism. ${ }^{28}$

Writing on October 29,1973 , he conjextured that the ". . time is ripe for private purchasing power bonds. A breakthrough awaits only our inaginative bond underwiter." The recenty amounced issue by Giticorp, a bank holding company anchored by the First National City Bank, New York, seems to be the response to Friedman's challenge. It has a provision for a variable interest rate one percent above the Treasury bill rate and redemption options at face values twice a year. This particular instrument may be interpreted as a form of de facto purchasing power bond if one regards changes in the Treasury bill rate as reflecting only the changes in the actual, rather than the antictpated, infation rate. To the extent that the changes in the Treasury bill rate incorporate changes in the underlying real interest rate, this instrument would have the added feature of reducing relative price risk as well 30

In order to explain the above assertion, let us anm alyze the relationship which would hold between an indexed and a nonindexed bond. Abstacting from risk-aversion, at the time of issue the interest rate set for a nonindexed bond would exceed the rate on an indexed bond by the expected rate of infation. Assume for simplicity that both are consols (bonds without maturity dates) and the indexed bond is protected for the full value of interest payments. What would happen to the market (present) values of these bonds as infationary expectations change? Market value of the indexed bond would be invariant with changed expectations of inflation, whereas that of the nonindexed bond would move inversely with the changes. As far as the change in the real interest rate is concemed, both bonds would be affected, but the variability of the indexed bond would be greater

\footnotetext{
28Milon Friedman, "Purchasing Power Bonds," Newsweek, 12 April 1971 , p. 86 , and Friedman, "Economic Miracles," Newstueek, 21 Jammary 1974, p. 80.

"Milton Friedman, "More on Living With Indation," News week, 29 October 1973, p. 96.

30A "true" purchasing power bond protects the holder only against price level changes, while leaving the holder vilnerable to relative price changes, that is, the risk of changes in the real interest rate, which refiects the exchange rate between presenti and future consumption options.
} 
for anticipated inflation. ${ }^{31}$ Assuming risk aversion, the relative attractiveness of the two bonds would crucially depend on the perceived relative variability of real interest rates and anticipated inflation rates. If the market judged that the expected rates of inflation were more volatile than real interest rates, again assuming risk aversion, the indexed bond would be relatively more attractive. Thus, it would command higher prices and lower effective yields; that is, a borrower may borrow at lower yield with the indexed bond than with the nonindexed bond. Avalable evidence from Israel is suggestive in this regard. ${ }^{32}$

The sometime advanced argument that the introduction of indexed bonds would adversely affect the price of existing bonds must then implicitly assume that the mere introduction would raise either the expected rate of infiation, which is debatable, or the real rate of interest, which is doubtful. The market price of existing bonds may be substantially below the original sale price, but this would be unrelated to the introduction of indexed bonds. The reduction would simply reflect the past history of movements in the market rates of interest, which reflect both the changes in the real rate and the inflation rate.

The introduction of indexed bonds would adversely affect the issuer of new nonindexed bonds. Under the assumed condition of relatively greater attractiveness for indexed bonds, the implied higher costs of borrowing for the incumbent borrowers mean lower wealth for the incumbent "conventional" borrowers. If there are legal impediments to issuing an indexed bond (possibly due to the statutory limits on both the lending and borrowing rates), the incumbents would lose wealth as the new indexed bonds joined the competition for funds.

It would not be surprising if those who stand to lose by the innovation would try to block access to the market in order to protect their wealh. The current lively counter-offensive by the thrift institutions to deny access to markets to the issuers of de facto

31This is becanse the elasticities of market values of indered and nonindexed consols with respect to a once-and-for-all change in the real rate of interest can be shown, respectively, as

$$
-\frac{\left(1+\Pi_{0}\right) \mathrm{rt}_{\mathrm{t}}}{\mathrm{r}_{\mathrm{t}}+\mathrm{r}_{\mathrm{t}} \Pi_{0}-\mathrm{r}_{0} \Pi_{0}} \text { and }-\frac{\left(1+\Pi_{0}\right) \mathrm{r}_{\mathrm{t}}}{\mathrm{rt}_{\mathrm{t}}+\mathrm{r}_{\mathrm{t}} \Pi_{0}+\Pi_{0}} \text {, }
$$

where $\Pi$ o is the rate of inflation anticipated at the time of contract formation, $r_{0}$ is the real rate of interest at the time of contract formation, and $r$ is the real rate of interest at time subsequent to contract formation. See the appendix, avalable on request, for demonstration

"2'Alexander Rubner, "The Abdication of the Israeli Pound as a Standard of Measurement for Medim and Long-Term Contracts," Retiew of Economic Studies (October 1960), pp. $69-75$. purchasing power bonds is instructive in this regard . $^{\text {a. }}$ The foregoing suggests that it is not so much the values of existing bonds but the wealth of the existing equity owner and/or the viability of certain finan. cial institutions which are threatened when indexed bonds are introduced without appropriate changes in the whole spectrum of legal and institutional arrangements.

The barriers to the introduction of indexation by the government and the private sectors are legal and economic. Indexing of income taxes and the issuance of index-linked government bonds would require legislative acts and the required legislation appears to entail significant political realignments. Opposition would appear to be concentrated in thrift industries such as savings and loan associations and mutual savings banks. The motive underlying opposition to indexation would appear to be the entailed loss in wealth consequent to the introduction of indexation without any provision to "socialize loss," such as a guaranteed purchase at par of the assets held by these institutions.

As noted recently by Professor Friedman, indexing income taxes would help facilitate the introduction of a private index-linked bond by exempting interest adjustments from the income tax levy. Indexing government securities would also stimulate the introduction of private indexed bonds by competitive forces as well as by preempting the state usury restrictions on loan contracts. The availability of index-linked instruments would facilitate the spread of indexation by providing hedging opportunities to such financial intermediaries as savings and loan associations, life instrance companies, and commercial banks.

\section{Longer Tem Conmats Would Result}

Under indexation longer-term contracts would likely result - a development which, on net conld be regarded as a benefit. Under a nonindexed regime with high and variable rates of inflation, the tendency toward shortening of maturity emerges because shortterm instruments provide a relatively higher degree of income and capital certainty. The above holds as Iong as the perceived variability in the expected rates of inflation is greater than that in the real interest rate. The Israeli experience, referred to earlier, tends to confirm this view.

Effective indexation would shelter the parties to a monetary contract from the effects of unanticipated

33: "Savings Assoctations Oppose Froposed Citicorp Note Issue," New York Times, 2 July 1974 , p. 55 . 
changes in the price level. However, the outcome would be differen from that of a nonindexed regime only if changes in the price level that occur are imperfectly anticipated. The transactors would eventually provide for anticipated changes in the price level in their contracts. The case for indexation, therefore, is essentially based on the judgment that anticipations about price level changes are neither uniform nor very accurate. Since divergent price expectations tend to restrict the extent of markets, indexation would apw pear to share most of the merits of a mantamed stable price level which generates zero expectations of price level change.

\section{Appropriate Index Not Resolved}

The claim of Irving Fisher, made over sixty years ago, that the theory and technique of index number construction was advanced enough to provide a standard monetary yardstick, appears to have been premature, ${ }^{34}$ The debate on indexation forcefully redirects our attention to a fundamental issue, namely, what is inflation and how do we measure it?

The concept of inflation can be defined only for an economy where money buys goods and goods buy money. Inflation is the sustained depreciation in the purchasing power of money and is measured by the construction of an appropriate price index. The reference to appropriate is crucial in undesscoring the difficulty involved in any attempt to construct a general price index. It brings into the open the fundamental issue of the appropriate universe of commodities in constructing the price index.

Should it contain intermediate goods or only final goods? Should it include only newly- produced goods and exclude all existing assets such as land and houses? Should it include only the currently pro* duced llow of services (such as housing services as measured by implicit rental payments) and exclude the currently produced sources of the future flow of services (such as houses and automobiles)? These are weighty and important issues to which satisfactory answers are yet to be given, even at a purely conceptual level..$^{35}$ The potential divisiveness over the choice of an appropriate index is discernible in labor's current opposition to the prospective revision of the consumer price index. ${ }^{36}$

\footnotetext{
HFisher, Purchasing Power.

"Anamen A Alchian and Benamin Klein "On a Correct Measure of Inflation," Joumal of Money, Credit and Bank. ing, Part I (February 1973), pp. 173.91.

$30^{c 4}$ Labor Bristies at a Broader CPI," Business Week, 6 Apri] 1974, p. 18.
}

\section{SUMMAPY}

If we abstract from history and ignore the inherited stock of outstanding monetary contracts and specialized financial institutions, the case for indexation appears persuasive. It would prevent the energence of an unintended distribution of income and thereby serve the cause of faimess. If indexation of income taxes and govemment obligations facilitates an effective check on "unauthorized" growth in the govern" ment's share of resources, its adoption would likely lead to govemment policies which would moderate the rate of inflation rather than exacerbate it. Inflationary policies would indeed lose constituency since the "honey" would have been sucked from such policies.

But, surely, the above reasoning is incomplete. It leaves unanswered the cuestion of how and why the shifting of the balance of political power, required to introduce indexation, would occur. Indexation per se would not cause the realigmment. Rather, realignment, should it occur, wonld be a retection of the "exogenous" shift in attitudes and distributions of effective political power.

We cannot, however, escape from our past nor remake the world anew at will by abolishing existing monetary obligations and financial institutions. We have an inherited stock of monetary contracts which incorporate past expectations of the paths of price level movements. Should the introduction of indexed bonds cause the previously held price expectations to change, a fortuitons change in the relative wealth of sellers and holders of outstanding monetary contracts would ensue. Specifically, should the anticipated (and experienced) rate of inflation fall as a consequence of the introduction of indexed bonds, net monetary debtors would lose wealth relative to net monetary creditors; conversely, net creditors would lose wealth relative to net debtors in the case where indexation induces a higher anticipated rate of inflation than was formerly held.

We have a set of institutions operating under inherited legal and regulatory constraints which restrict their range of asset and liability choices. Should indexation be perceived as inimical to the vested interests of certain groups, opposition to its adoption would undoubtedly be mobilized in the absence of a credible plan to "socialize" the total cost of transition. Advocacy of indexation seldom is accompanied by such a plan, and hence will be met by the organized opposition of those who are likely to be hurt by its 
adoption. The opposition will not likely be assuaged by a demonstration that indexation will serve the general interest.

We can discern the following three possible denouments for indexing govermment revenues and obligations:

(1) Indexation may be adopted over opposinon through the contest of relative political power.

(2) Indexation may be adopted with the consent of the former opposition when a credible plan to compensate the potential losers is appended as a zider. Stch a plan may include a guaranteed purchase at par of existing mortgages held by thrift institutions.
(3) Indexation may, of course, be rejected even if the balance of benefits over losses is shown to be positive.

As noted earlier, however, a partial indexation in the sphere of private wage contracts and public pension contracts is with us already. The question of remowing the legal barriers to indexing private loan and deposit contracts still remains. The recent proposal by the Canadian government to "inflaton-proof" its income tax structure may be the wave of the future. The overriding question, however, is the degree of restraint that revenue indexation would impose on the govermment's demand for a greater share of scarce resources.

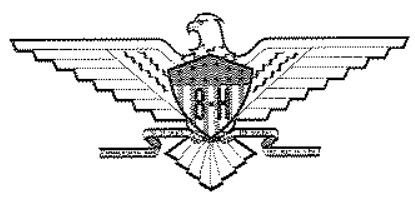

